\title{
PENGEMBANGAN MODEL SUPERVISI KLINIS BERBASIS INFORMASI DAN TEKNOLOGI
}

\author{
Rugaiyah \\ Fakultas Ilmu Pendidikan Universitas Negeri Jakarta \\ Email: rugaiyahfitri@gmail.com
}

\begin{abstract}
Abstrak: Penelitian bertujuan mengembangkan model supervisi klinis berbasis informasi dan teknologi. Penelitianini adalah penelitian dan pengembangan $(R \& D)$, meliputi tahap-tahap research and information collecting, planning, develop preliminary form of product, preliminary field testing. main product revision, main field testing, operational product revision, operational field testing, final product revision, dissemination and implementation. Data dikumpulkan lewat wawancara dan dokumentasi serta dianalisis secara deskriptif kualitatif. Hasil penelitian adalah sebagai berikut. Pertama, berdasarkan kajian konsep model supervisi klinis dikembangkan berbasis konsep yang dikemukakan Glickman lewat lima tahap: (1) prakonferensi dengan guru; (2) observasi kelas; (3) analisis interpretasi observasi dan menetapkan pendekatan konverensi; (4) pertemuan yang dilakukan setelah melakukan observasi; (5) pelaksanaan kritik empat langkah. Kelima tahapan tersebut dilakukan dengan memanfaat informasi dan teknologi. Kedua, persepsi dan pemahaman guru, kepala sekolah tentang supervisi klinis belum tuntas. Ketiga, mengembangkan panduan supervisi klinis berbasis informasi dan teknologi sebagai terobosan untuk memandu guru meningkatkan kompetensi mengajarnya dan pihak yang terlibat pelaksanaan supervisi klinis berbasis informasi dan teknologi.
\end{abstract}

Kata Kunci: supervisi klinis, informasi dan teknologi, kompetensi guru

\section{DEVELOPING INFORMATION AND TECHNOLOGY-BASED CLINICAL SUPERVISION MODEL}

\begin{abstract}
This study aims to develop a model of clinical supervision based on information and technology. It belongs to research and development ( $\&$ \&), which includes research and information collection, planning, developing preliminary form of product, preliminary field testing, product revision, field testing, operational product revision, field operational testing, final product revision, and dissemination and implementation. Based on the stages of R \& D, the findings can be explained as follows. Firstly, based on the study of the concept ofclinical supervision model, five stages proposed by Glickman were implemented, namely: (1) pre-conference with the teacher; (2) classroom observations; (3) the analysis and interpretation of the observation results and set up thekonverensi approach; (4) meetings after observing; (5) evaluating the four stages. All stages were carried out by utilizing information and technology. Secondly,teachers' and headmaster's perception or understanding on clinical supervision is yet complete. Thirdly,information and technology-based clinical supervision can be considered as a breakthrough for guiding teachers to improve their teaching competence and for helping relevant parties in carrying out clinical supervision.
\end{abstract}

Keywords: clinical supervision, information and technology, teacher competence

\section{PENDAHULUAN}

Kegiatan supervisi dilakukan dalam upaya memperbaiki dan mengontrol segala aktivitas agar terlakasana secara optimal. Pengawasan/ supervisi adalah memastikan kegiatan secara efektif dilaksanakan oleh mereka yang bertanggung jawab untuk melakukannya. Supervisor biasanya mereka yang fokus pada kegiatan sehari-hari dari departemen dan mengevaluasi mereka yang melakukan mereka. Manajer paling efektif dan supervisor juga pemimpin (Hess, Matison, Orthmann, 2012:5). Supervisi klinis merupakan praktek khusus berada pada tingkat tertinggi pada praktek kerja sosial karena supervisor klinis mempersiapkan pekerja sosial untuk berlatih mandiri tanpa perlu pengawasan lebih 
lanjut (Openshaw,2012:2). Pengertian supervisi klinis diadopsi dari profesi medical yaitu proses mengembangkan keterampilan dan pengetahuan peserta pelatihan dalam kegiatan praktik.

Model Integratif merupakan model supervisi yang dikembangan dalam bidang kesehatan yaitu model yang dikembangakan untuk meningkatkan psikoterapi dan pengawasan, yang di sebut sebagai 'model FIT'. psikoterapis ini disebut sebagai terapis. Model FIT didirikan pada tiga domain dari fungsi manusia: Feeling (F) Memulai; Initiating (atau akting) (I) Thinking (T) model FIT dikembangkan dari kebutuhan yang dirasakan untuk model terapi dan pengawasan, bukannya terbatas pada teori psikologi tunggal dan pendekatan, menggunakan pendekatan holistik yang menggabungkan berbagai teori dan isu-isu (Harris \& Brockbank,2011:15).

Kegiatan pendidikan supervisi dilaksanakan dalam rangka memperbaiki kegiatan pembelajaran. Pada umumnya supervisi yang dilakukan saat ini muncul atas inisiatif kepala sekolah atau pengawas bukan dari guru. Idealnya upaya memperbaiki kegiatan pembelajaran datang dari guru yang bersangkutan, bukan dari pihak lain. Inisiatif memperbaiki kemampuan mengajar datang dari guru itu sendiri sangat pen-ting untuk dikembangkan yang merupakan benih yang segera dikembangkan menjadi kegiatan peningkatan kemampuan guru berbasis kesadaran, hal merupakan inti dari konsep supervisi klinis. Tujuan supervisi klinis adalah membantu guru mengembangkan dan meningkatkan profesionalitasnya melalui perencanaan bersama (guru dan supervisor), observasi dan umpan balik (Esim dkk, 2013:191-203). Model supervisi Klinis dikembangkan pula oleh Baltacy dkk (2014:111). Konsep yang dikembangkan diadopsi dari Acheson \& Gall, yaitu mengembangakan lima tahap supervisi klinis yaitu "The CSM cycle includes pre-conference, observation and data collection, data analysis, post-conference, and reflection stages. Kelima tahap yang dimaksud ditunjukkan pada Gambar 1.

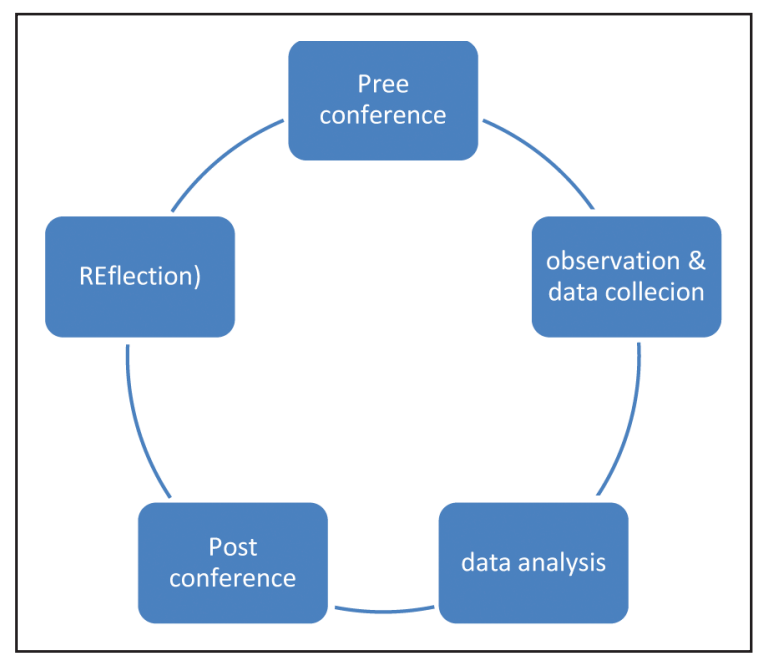

\section{Gambar 1. Clinical Supervision Model Diadopsi dari Acheson \& Gall}

Berdasarkan hasil studi pendahuluan, secara empiris ditemukan hal-hal sebagai berikut. Pertama, sebagian kepala sekolah, guru bahkan supervisor belum memahami secara utuh apa yang dimaksud dengan supervisi klinis. Kedua, kegiatan supervisi masih dipersepsikan sebagai program kepala sekolah dan program pengawas. Sehingga guru bersifat pasif menunggu kapan kepala sekolah atau pengawas sempat mensupervisi guru tersebut. Ketiga, membina guru merupakan salah satu tugas dari supervisor, dan menjadi program sekolah, bila kondisi demikian nampaknya guru pasif untuk meningkatkan kemampuan mengajar. Keempat, pada kondisi nyata $\mathrm{h}$ guru harus disupervisi dan banyak jumlahnya, sedangkan waktu terbatas, maka melalui bantuan informasi dan teknologi dapat dijadikan salah satu strategi untuk membina guru dengan mensiasati strategi waktu tanpa harus bertemu dalam waktu nyata (real time) pada setiap tahap supervisi klinis, karena dengan menggunakan media informasi dan teknologi (IT) komunikasi akan tetap berlangsung tanpa kendala waktu harus bertemu secara berkala dengan frekuensi yang sering.

Kondisi tersebut menjadi dasar berpikir yang divisualisasikan pada Gambar 2.

Kegiatan supervisi menjadi tugas pokok dan fungsi kepala sekolah dan pengawas, kegiatan supervisi bertujuan untuk meningkatkan kegiatan pembelajaran, pada kondisi tersebut guru tampak pasif. Upaya meningkatkan kegiatan pembelajaran idealnya tumbuh dari guru itu sendiri bukan dari kepala sekolah atau pengawas wilayah. Supervisi klinis merupakan upaya yang dilakukan 


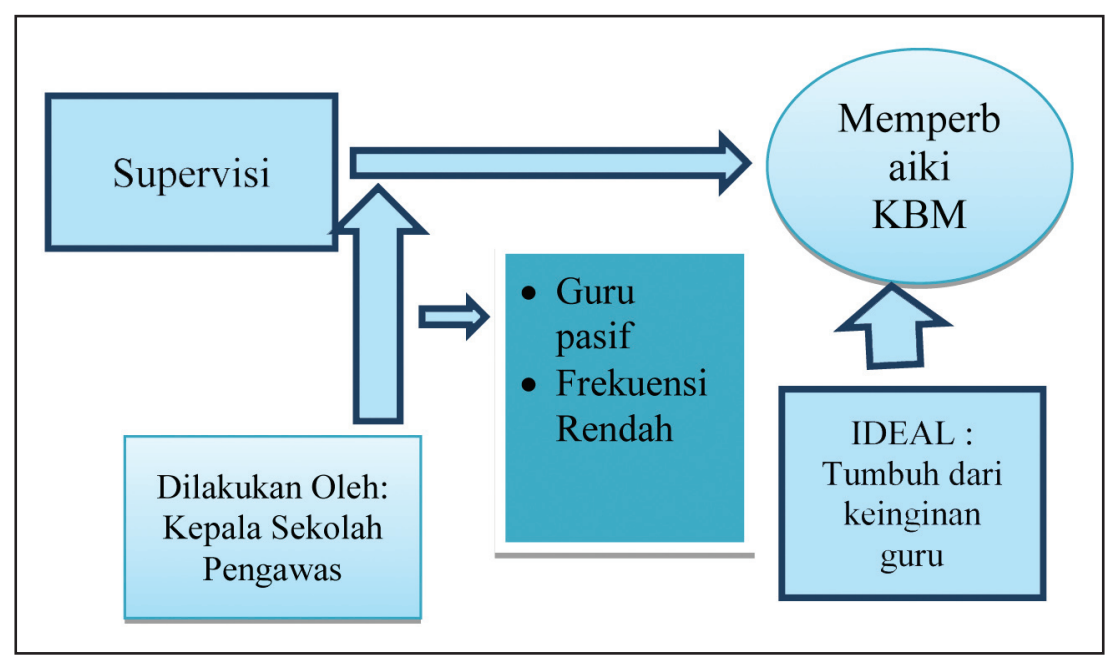

Gambar 2: Kerangka BerpikirAwal

untuk meningkatan kemampuan belajar siswa dan kemampuan mengajar guru, dengan beberapa tahapan. Glickman dkk (2010:288-289) menjelaskan lima langkah supervisi klinis, yaitu: (1) pra konferensi dengan guru; (2)observasi kelas; (3) analisis interpretasi observasi dan menetapkan pendekatan konverensi; (4) pertemuan yang dilakukan setelah melakukan observasi; (5) Melakukan kritik empat langkah sebelumnya. Langkah tersebut diviasualisasikan pada Gambar 3.

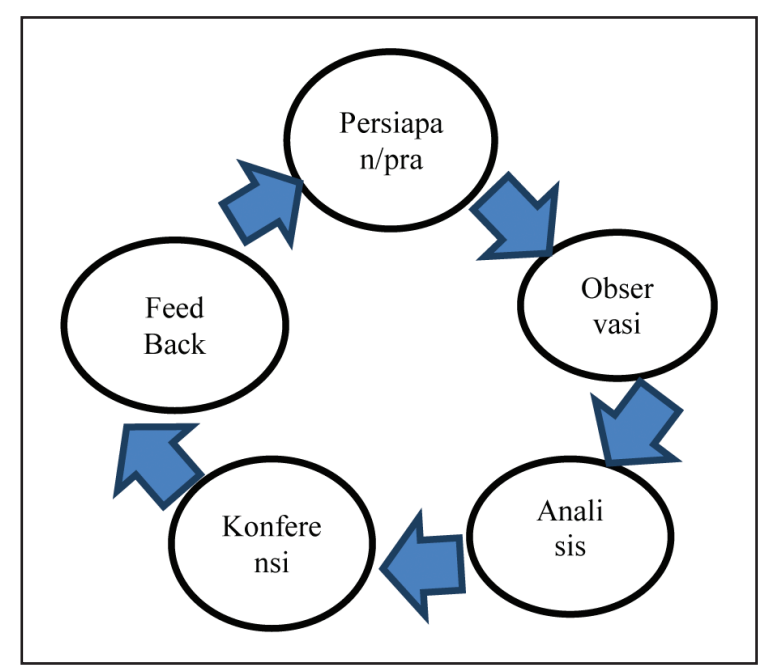

\section{Gambar 3: Lima Langkah Supervisi Model Glickman}

Berdasarkan kajian hasil penelitian, kajian konsep,masalah empiris dan kerangka berpikir, penelitian ini memfokuskan pada masalah bagaimana merancang "Pengembangan model supervisi klinis berbasis informasi dan teknologi dalam upaya meningkatkan kompetensi guru”.

Penelitian ini merancang panduan-panduan yang dijadikan pedoman untuk melaksanakan supervisi klinis berbasis informasi dan teknologi bagi para personal yang terlibat (stakeholder). Saat ini teknologi informasi sudah semakin canggih, teknologi informasi merupakan teknologi yang dapat membuat/menyajikan dan mengolah data informasi dengan jenis yang bervariasi, seperti: komputer, handphone, kamera, dan sebagainya. Saat ini penggunaan teknologi informasi sudah digunakan dalam kehidupan sehari-hari bahkan sudah menjadi suatu kebutuhan, juga digunakan di dalam proses pembelajaran. Guru dapat memanfaatkan teknologi informasi dalam melakukan supervisi klinis. Prosedur supervisi klinis mencakup: perencanaan pertemuan, observasi, analisis data, pertemuan balikan untuk refleksi kolaborasi.

Cogan melihat supervisi klinis sebagai wahana untuk mengembangkan guru agar bertanggung jawab secara profesional yang mampu menganalisis kinerja mereka sendiri, yang terbuka untuk perubahan dan bantuan dari orang lain terutama dalam mengarahkan diri sendiri. Richard Wellers dalam Sullivan mengatakan: "Supervisi klinis dapat didefinisikan sebagai pengawasan yang difokuskan pada perbaikan pengajaran melalui siklus yang sistematis yang terdiri dari perencanaan, observasi dan analisis intelektual yang intensif tentang pengajaran yang sebenarnya untuk kepentingan perubahan yang rasional", Sullivan and Glanz (2013: 120-121). Sergiovanni mengatakan, "Clinical supervision is a way in which teachers can collaborate together to research their practice and improve their learning and their teaching." Sergiovanni \& Starratt (2006: 22) 
Terdapat satu hal penting tentang bagaimana seorang guru secara terus-menerus diharapkan meningkatkan kompetensinyanya dalam menjalankan profesi seorang guru secara profesional. Guru harus mempertahankan dan mengembangkan kompetensinya. Seorang guru harus memiliki kompetensi mengajar yang baik, Kevin $\mathrm{Wu}$ (2010:99) mengatakankompetensi adalah kemampuan yang wajib dimiliki oleh seseorang untuk tampil atau berperan dalam tugas-tugas tertentu. Pardjono \& Suyanto (Mulyana(2010: 110) mengatakan bahwa kompetensi adalah seperangkat tindakan cerdas dan penuh tanggung jawab yang dimiliki seseorang sebagai syarat memperoleh pengakuan dari masyarakat, dalam melaksanakan tugas-tugas tertentu.

Berdasarkan pendapat di atas dapat disimpulkan bahwa kompetensi mengajar senantiasa berkembang sesuai dengan perkembangan zaman sehingga guru perlu meningkatkan kompetensi yang dimiliki agar dapat mengajar dengan baik. Guru yang mampu menguasai materi pelajaran dengan baik maka akan mudah menyampaikan atau mentransfer pengetahuan yang dia miliki kepada peserta didik.

\section{METODE}

Penelitian ini adalah model penelitian dan pengembangan (R\&D). Borg dan Gall (2008:775776) mengemukakan bahwa ada sepuluh langkah dalam pelaksanaan R\&D. Langkah-langkah tersebut secara lengkap dijelaskan berikut. Pertama, research and information collecting yaitu melakukan kajian literatur yang berkaitan dengan supervisi klinis. Pada tahap ini peneliti melakukan kajian literatur yang berkaitan dengan konsep supervisi klinis, kompetensi mengajar guru dan teknologi informasi yang dimanfaatkan oleh guru, pengawas dan kepala sekolah dalam upaya merealisasikan kegiatan supervisi klinis.

Kedua, planning yaitu mengumpulkan informasi dan melakukan penelitian awal tentang pemahaman persepsi guru, kepala sekolah dan pengawas terhadap kegiatan supervisi klinis. Untuk mendapatkan informasi tersebut peneliti melakukan studi melalui kegiatan wawancara tentang supervisi klinis, sumber informannya meliputi; kepala sekolah, pengawas dan guru, hasil tersebut dideskripsikan menjadi informasi dasar dalam melakukan tahapan penelitian berikutnya. Untuk melakukan kegiatan wawancara peneliti membuat panduan wawancara. Ketiga: develop preliminary form of product, melakukan perencanaan dalam bentuk pengembangan penyusunan panduan dan instrumen supervisi klinis, pada tahap ini tim peneliti melakukan kegiatan menyusun panduan supervisi klinis, instrumen penilian supervisi klinis untuk guru dan supervisor. Panduan rekaman video yang diperuntukan bagi kameramen (orang yang melakukan kegiatan pengambilan film video).

Keempat:preliminary field testing. Melakukan expert judgement, instrumen diberikan kepada tim ahli untuk melakukan validasi panduan dan instrumen supervisi untuk guru dan supervisor. Selanjutnya peneliti akan melakukan uji coba pertama lapangan penggunaan panduan dan instrumen supervisi klinis kepada 1 guru, 1 kepala sekolah dan 1 pengawas. Kelima: main product revision, melakukan revisi panduan dan instrumen yang setelah kegiatan penggunaan panduan dan instrumen supervisi klinis oleh user berdasarkan masukan dari expert dan praktisi supervisi, pengawas maupun kepala sekolah. Keenam: main field testing. Pada bagian ini peneliti akan melakukan uji coba keduapanduan dan instrumen supervisi klinis kepada 1 guru, 1 kepala sekolah dan 1 pengawas.

Ketujuh: operational product revision, melakukan revisi setelah kegiatan penggunaan panduan dan instrumen supervisi klinis oleh user berdasarkan masukan dari expert dan praktisi supervisi. Kedelapan: operational field testing. Melaksanakan uji validasi dengan jumlah sampel yang dapat dijangkau, yaitu 12 guru, 6 kepala sekolah, dan 3 pengawas. Melakukan pengumpulan data tentang penggunaan panduan dan instrumen supervisi klinis melalui wawancara, observasi, kuesioner, selanjutnya data tersebut dianalisis. Kesembilan: final product revision, melakukan revisi terakhir secara keseluruhan setelah mendapat masukan dari hasil kegiatan penggunaan panduan dan instrumen supervisi klinis di lapangan. Kesepuluh: dissemination and implementation. Menyampaikan laporan penelitian ini dalam sebuah seminar hasil penelitian dan juga ke dalam jurnal ilmiah.

Penetapan sampel penelitiannya dilakukan dengan teknik purposive sampling karena penetapan sampel yang terkait menjadi subjek penelitian harus memiliki kemampuan kolaborasi dan perhatian yang cukup intensif terhadap proses penelitian ini. Sebaran sampel penelitian dipilih 10 guru, 3 pengawas yang bertugas di wilayah 
Jakarta, 4 guru dan 2 pengawas yang bertugas di wilayah Depok dan Bekasi.

Teknik pengumpulan data dilakukan melalui wawancara kepada para pengawas, kepala sekolah dan guru. Instrumen adalah peneliti langsung dibantu dengan pedoman wawancara. Data terkait tentang expert judgment dilakukan dengan mengundang ahli manajemen pendidikan dan ahli teknologi dalam hal ini adalah ahli dari teknologi pendidikan. Instrumen yang digunakan dalam bentuk format analisis terbuka terkait validasi panduan supervisi klinis dan panduan rekaman video. Pengumpulan data pengambilan data rekaman video dilakukan langsung oleh tim peneliti ke sekolah sasaran berdasarkan statel sebaran wilayah sekolah dasar yang terletak kabupaten/kota.

\section{HASIL DAN PEMBAHASAN}

Hasil penelitian dideskripsikan sesuai tahapan penelitian reseacrh and development sebagai berikut.

Pertama, melakukan kajian literatur yang terkait supervisi klinis, hasil kajian tersebut menghasilkan kerangka berpikir awal penelitian yang ditunjukkan pada Gabmar 4.

Hasil kajian konsep dikembangkan dari Glickman supervisi klinis itu terdiri dari lima tahap, yaitu tahap pertama persiapan/pertemuan awal, kedua tahap oservasi, tahap ketiga analisis interpretasi, tahap keempat pertemuan pasca observasi dan kelima pertemuan balikan. Langkah tersebut membutuhkan waktu yang panjang, jumlah guru banyak, frekuensi pertemuan rendah, secara empiris diduga sulit dilaksanakan secara optimal untuk memenuhi lima langkah tersebut, maka digunakan terobosan memanfaat informasi dan teknogi untuk melakukan supervi klinis. Untuk melakukan itu diperlukan pandun-panduan untuk menjadi acuan dalam melaksanakan supervisi klinis.

Kedua, pemetaan persepsi tentang supervisi klinis berdasarkan hasil wawancara kepada para informan yang diklasifikasikan sebagai informan guru, kepala sekolah dan pengawas. Persepsi yang dimaksud menggali tentang wawasan supervisi klinis, pengalaman dalam kegiatan supervisi klinis, dilanjutkan dengan menggali informasi dampak supervisi dengan peningkatan hasil pembelajaran siswa dan peningkatan kompetensi guru.

Hasil wawancara informan kepala sekolah, diperoleh gambaran tentang wawasan supervisi klinis. Sebagian kepala sekolah mengatakan bahwa ia mengetahui bahkan pernah mendapat pelatihan, tetapi setelah dilakukan wawancara mendalam tidaksesuai dengan konsep supervisi klinis. Sampai saat ini, pelaksanaan supervisi

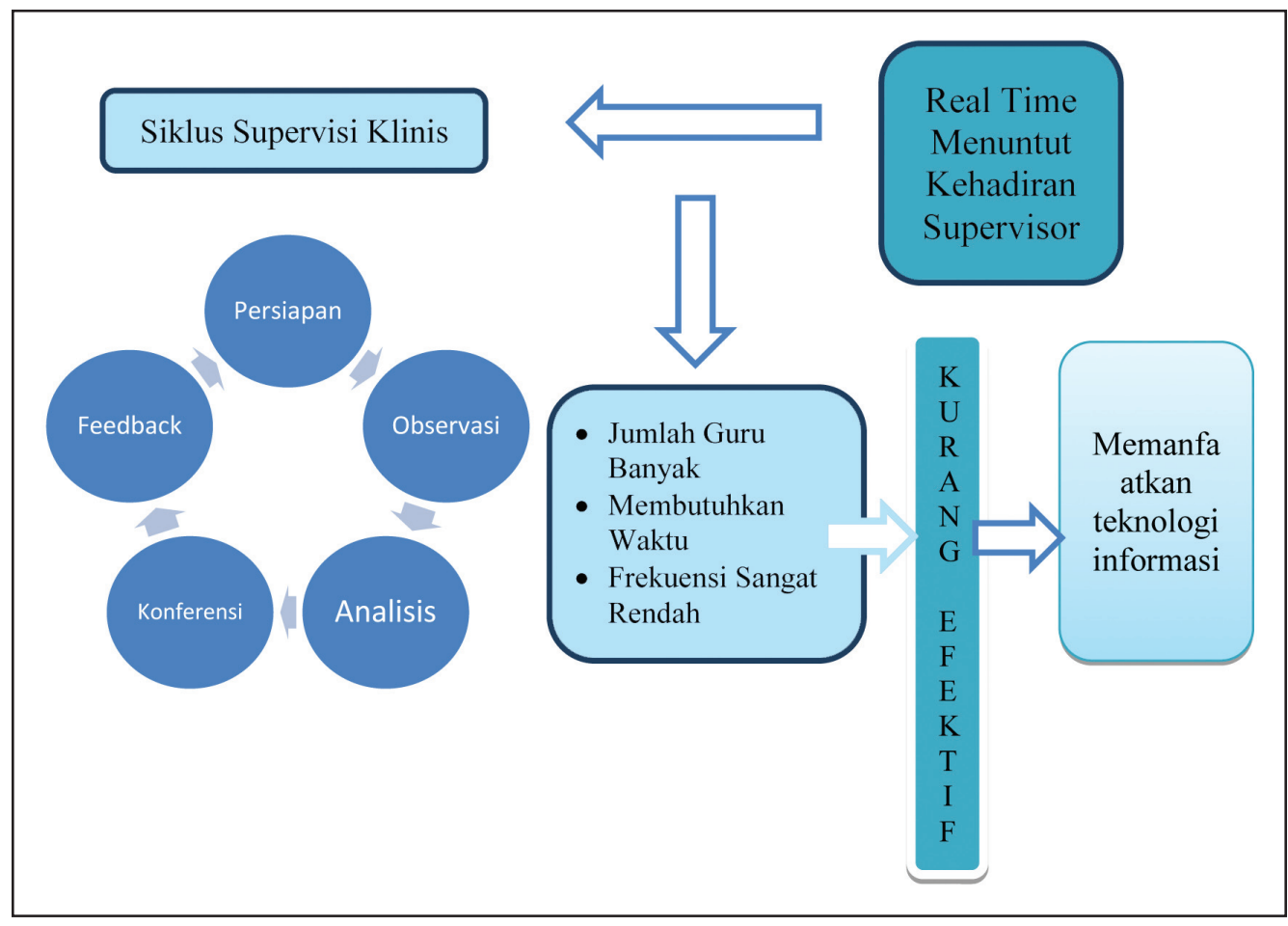

Gambar 4: Kajian Konsep Penelitian "Pengembangan Model Supervisi Klinis Berbasis Informasi dan Teknologi 
berdasarkan program yang telah ditetapkan oleh sekolah, biasanya dilakukan satu satu kali dalam satu semester. Sebelum melaksanakan supervisi diadakan kesepakatan dengan guru mengenai jadwal pelaksanaan supervisi ataukunjungan kelas. Hasil wawancara kepada informan pengawas, seluruh pengawas mengerti apa yang dimaksud dengan supervisi klinis, dan mengetahui dimulai dari temuan masalah yang dihadapi guru, dan memberikan pembinaan berdasarkan permasalah yang dihadapi guru, bila tidak ada masalah tidak perlu disupervisi, tetapi diakui bahwa supervisi klinis belum dapat dilakukan optimal karena guru masih merasa takut untuk mengajukan permintaan untuk disupervisi oleh kepala sekolah atau pengawas.

Berdasarkan hasil pemetaan studi awal di atas ditemukan, pertama guru belum memahami supervisi klinis, guru hanya memahami supervisi pada umumnya, kedua kepala sekolah sudah memahami tentang supervisi klinis, tetapi kepala sekolah melaksanan supervisi hanya untuk pemenuhan program supervisi pada umumnya. Ketiga pengawas sudah memahami tentang supervisi klinis tetapi belum melaksanakannya, disebabkan oleh ketidakpahaman guru dan kepala sekolah. Maka pada langkah berikut peneliti membuat panduan supervisi klinis serta instrumen yang diperlukan untuk melakukan supervisi klinis berbasis teknologi dan informasi.

Ketiga, develop preliminary form of product, menghasilkan dokumen panduan supervisi klinis dan panduan rekaman video, panduan ini bertujuan untuk memberikan pemahaman kepada guru untuk meningkatkan kompetensi mengajarnya, para pihak yang terlibat dalam melaksanakan supervisi klinis.

\section{Panduan Supervisi Klinis}

Sistematika panduan diawali pendahuluan, tujuan panduan, pengguna panduan, definisi operasional, mekanisme kegiatan, pihak yag terlibat, penutup. Pendahuluan berisi tentang konsp tentang supervisi klinis berbasis informasi dan teknologi sebagai salah satu alternatif untuk mengatasi keterbatasan ruang dan waktu dalam melaksanakan supervisi klinis baik oleh supervisor dan kepala sekolah, bagi guru untuk menumbuhkan kesadaran bahwa perbaikan mengajar harus diawali dari guru sendiri. Pengguna panduan ini diperuntukkan bagi guru sebagai sasaran supervisi klinis dalam meningkatkan kompetensi mengajar, pengawas untuk melaksanakan pembinaan, dan kameramen yang membantu guru dalam melakukan rekaman. Panduan ini secara lengkap dapat diakses melalui https://1 drv.ms/b/ s!AgjlleNs0UxKgm5nopi1KcD1e7gY.

\section{Panduan Rekaman Video}

Panduan rekaman video ini dimaksudkan untuk memberikan pedoman kepada kameraman dalam melakukan pengambilan gambar, berisi petunjuk pengambilan gambar dan perangkat yang digunakan. Pertama kameramen menyediakan handphone atau kamera digital dengan memory eksternal yang besar, melakukan shooting dengan close up, medium dan gerakan ke kiri dan ke kanan. Rekaman dilakukan pada saat kegiatan pembukaan, dengan melakukan shoot depan lalu shoot ke kiri dan kekanan. Pada saat inti kamera diarahkan dari bagian belakang ruang kelas agar lebih jelas melihat kegiatan yang dikerjakan oleh guru, lalu camera diarahkan ke kiri dan ke kanan mengikuti gerakan guru. Pada saat kegiatan penutup kamera shoot dari belakang clse up ke guru, lalu diarahkan ke murid untuk melihat ekspressi murid pada akhir pelajaran kembali diarahkan ke guru untuk mengakhiri pelajaran. Panduan dapat diakses melaluihttps://1drv. ms/b/s!AgjlleNs0UxKgm9m677vqwqeIpWe. Rekaman contoh video pembelajaran di SD Negeri yang dijadikan salah satu contoh dapat diakses melalui https://1drv.ms/v/ s!AgjlleNs0UxKgwPDQkldXP_wBqJK.

Keempat, pelaksanaan expert judgement. Kegiatan ini dilakukan dengan mengundang para ahli untuk memberikan masukan pada panduan agar panduan menjadi lebih valid atau tepat, ekspert yang memberikan masukan tentang panduan supervisi yang memiliki keahlian manajemen pendidikan,untuk instrument supervisi juga yang memiliki keahlian manajemen pendidikan. Untuk ahli yang memberikan masukan panduan shooting adalah ahli teknologi pendidikan. Berdasarkan hasil masukan dari ahli panduan supervisi diperbaiki dengan menambah menjelaskan definisi oprasional, sedangkan untuk istrumen supervisi hanya memperbaiki pernyataan dan teknik skoring.

Untuk panduan rekaman video, ternyata masih banyak yang harus diperbaiki paning (gerakan ke kiri dan gerkan ke kanan), pada panduan pertama tidak disusun story board yang menggambarkan langkah shooting dengan jelas dan sisitimatis, juga dilengkapi dengan gambar 
untuk tahapan shooting, serta memperbaiki istilah dalam pengambilan gambar, seperti gerakan geser ke kiri dan ke kanan, istilah yang betul adalah paning. Selanjutnya peneliti mengadakan uji coba panduan ke lapangan. Sebelum melakukan kegiatan penelitian tim peneliti mengdakan koordinasi dengan pihak dinas pendidikan dengan mengirim surat izin penelitian.

Untuk tahap pertama peneitian dilakukan di kecamatan Rawajati di Sekolah Dasar (SD) Negeri 08 pagi, dilakukan koordinasi dengan pihak kepala sekolah dan guru yang menjadi objek penelitian. Pada hari yang disepakati tim peneliti melakukan pengambilan video/shooting mengajar guru kelas satu di Sekolah Dasar Rawajati 08, berlangsung satu jam pelajaran. Pengawas belum menggunakan email untuk memberikan panduan kepada guru, tetapi diberik secara manual hard copy. Guru belum melakukan permohonan untuk disupervisi via email.

Kelima, main product revision, revisi panduan dan instrumen setelah dilakukan uji coba lapangan, diperoleh masukan dari kameramen bahwa pengambilan gambar dilakukan dengan menggunakan kamera digital atau handphone. Ahli teknologi dan informasi memberikan masukan bahwa pengambilan gambar dilakukan dalam one shoot dan kameramen cukup standing on one place (berdiri tetap di satu tempat) deret akhir tempat duduk siswa.Berdasarkan masukan dari guru dan kepala sekolah instrumen perlu diberikan petunjuk yang lebih jelas untuk penggunaannya.

Keenam, main field testing, pada bagian ini peneliti melakukan uji coba kedua panduan dan instrumen supervisi kepada satu guru dan satu kepala sekolah dan satu pegawas. Uji coba kembali diaawali dengan koordinasi kepada pihak sekolah, dalam hal ini dilakukan di SD 05 pagi Rawajati, peneliti melakukan izin penelitian satu minggu sebelum kegiatan, dilanjutkan dengan pertemuan pendahuluan kepada kepala sekolah juga untuk koordinasi dengan guru yang akan menjadi objek penelitian. Diawali dengan guru mengirim email kepada supervisor/ kepala sekolah agar mensupervisi kegiatan pembelajaran, selanjutnya ada kesepakatan antara guru dan supervisor untuk melaksanakan kegiatan supervisi. Selanjutnya kepala sekolah berkoordinasi dengan tim untuk melakukan rekaman video pembelajaran. Pengambilan rekaman video dilakukan di kelas 3. Setelah selesai pengambilan gambar, kameramen memberikan hasil rekaman kepada guru dan supervior untuk dianalisis.
Ketujuh, operational product revision, revisi setelah kegiatan penggunaaan panduan dan instrumen supervisi klinis oleh penggunan berdasarkan masukan dari ahli dan praktisi, pada tahap ini panduan dan instrument hanya diperbaiki pada kesempurnaan redaksi untuk memudahkan penggunaan instrumen bagi pihak-pihak yang terlibat.

Kedelapan, operasional field testing, uji validasi dengan jumlah sampel yang dapat dijangkau yaitu 12 guru, 7 kepala sekolah dan 5 pengawas, sampel sasaran meliputi: Untuk provinsi di DKI Jakarta diambil 5 sekolah dasar meliputi: SD Rawajati 05 Pagi, Rawajati 08 Pagi, Gunung 01 Pagi, Gunung 03 Pagi, Dukuh 03 pagi SD kota Bekasi satu sekolah yaitu SD Jatirasa 03 pagi dasar dan Kota Depok satu sekolah Dasar. yaitu SD Tugu 10 Pagi. Pengawas SD kecamatan Pancoran, kecamatan Kebayoran Baru, Kramat jati. Kota Depok: kecamatan Cimanggis dan Kota Bekasi dari Kecamatan Jatiasih.

Sebelum dilakukan uji validasi lapangan, diadakan sosialisasi ke sekolah tentang kegiatan supervisi klinis berbasis teknologi, Untuk kegiatan sosialisasi peneliti lakukan dengan mendatangi tiap sekolah, yang akan dijadikan sasaran, dengan tujuan untuk penjajagan awal mengetahui situasi kondisi sekolah dan kelas yang akan dijadikan sasaran penelitian. Kegiatan sosialisi dilakukan kepada pengawas sebagai pembina sekolah, kepala sekolah, dan guru-guru, khususnya guru yang akan dijadikan sasaran penelitian. Hasil pelaksanaan uji validasi mengikuti tahapan supervisi klinis yaitu: tahapan pertemuan awal, pada model ini dapat dilakukan dengan menggunakan informasi dan teknologi, komunikasi dilakukan melalui email, short service massage (SMS), telepon dan lainnya.

Tahap kedua, rekaman video kegiatan pembelajaran minimal satu jam pelajaran, koordinasi dengan kameramen atau petugas yang bertugas mengambil gambar. Transfer video ke prangkat flasdisk, compact disk atau langsung ke komputer, melakukan pemutaran ulang film. Tahap ketiga, penilaian melalui pemutaran video pembelajaran guru sasaran, hal ini dilakukan oleh guru sendiri, kepala sekolah dan pengawas. Tahap keempat (konferensi); supervisor dan guru dapatmelakukannya melalui video call, juga dapat dibarengi dengan tahap lima. Selanjutnya tahap lima memberi balikan (feed back) merancang pertemuan balikan melakukan tatap muka antara supervisor (pengawas) dan guru yang disupervisi. 
Kegiatan pada tahap operasional filed testing (Uji validasi lapangan) dengan melibatkan12 orang guru SD, 7 kepala SD, dan 5 pengawas sekolah dasar. Hasil validasi user guru, praktisi lapangan adalah kepala sekolah dan pengawas. Analisis pembelajaran dilakukan oleh guru sebagai subjek yang menjadi obyek penelitian, kepala sekolah dan pengawas sekolah, melakukan analisis hasil mengajar guru menggunakan instrumen yang telah disediakan. Hasil kegiatan, instrumen tersebut dapat digunakan dengan cermat, pengawas dan guru menuangkan hasil analisisnya pada lembar instrumen yang telah disediakan. Kameramen melaksanakan rekaman video sesuai panduan.

Kesembilan, final product revision. Penyusunan panduan dan instrumen tersebut dilakukan melalui uji validasi dari ahli/expert dan praktisi lapangan, sebagai revisi terakhir dilakukan dengan mereview kembali setelah dilaksanakan penggunaaan panduan dan instrumen supervisi klinis di beberapa sekolah. Panduan dan Instrumen tersebut dalam bentuk panduan supervisi klinis, panduan rekaman gambar video dan instrumen penilaian mengajar guru.

Kesepuluh, dissemination and implementation. Penyebaran dan pelaporan, pertama peneliti menjadi pembicara tentang supervise klinis berbasis informasi dan teknologi dalam kegiatan Pengabdian Masyarakat di Sekolah Dasar Negeri Pembina Provinsi DKI Jakarta, kegiatan dan dilanjutkan dengan peraktek supervisi klinis berbasis informasi dan teknologi oleh Sekolah Dasar Negeri Cipinang Muara 05 Pagi yang menjadi model dalam kegiatan tersebut. Kedua dilakukan dengan mempublikasiskan hasil penelitian melalui jurnal

\section{Pembahasan}

Penelitian Model Supervisi Klinis Berbasis Teknologi Informasi dikembangkan dari konsep Glickman et al (2010: 288-289) menjelaskan lima langkah supervisi klinis (1) pra konferensi dengan guru (tahap persiapan); (2) observasi kelas;(3) analisis interpretasi observasi dan menetapkan pendekatan konferensi; (4) pertemuan yang dilakukan setelah melakukan observasi; (5) pelaksanaan kritik empat langkah sebelumnya. Konsep awal supervisi klinis adalah kegiatan supervisi yang ditujukan untuk perbaikan mengajar guru khusus satu keterampilan mengajar tertentu.

Penelitian ini mengembangkan model supervisi klinis berbasis teknologi dan informasi yang membedakan model tersebut dari konsep awal adalah antara satu tahap dengan tahap yang lain dapat menggunakan informasi dan teknologi. Penggunaan teknologi dan informasi dapat memotong siklus keterbatasan ruang dan waktu. Model tersebut dapat di divisualisasikan pada Gambar 5.

Pada tahap awal dilakukan pertemuan awal saat pertemuan akademik yang selanjutnya dilakukan melalui pemanfaatan informasi berbasis teknologi dan informasi bisa menggunakan email, SMS, atau via telepon. Adapun persiapan untuk membuat RPP dan dikonsultasikan dengan supervisor dalam hal ini kepala sekolah atau pengawas binaan yang biasanya dilakukan dengan

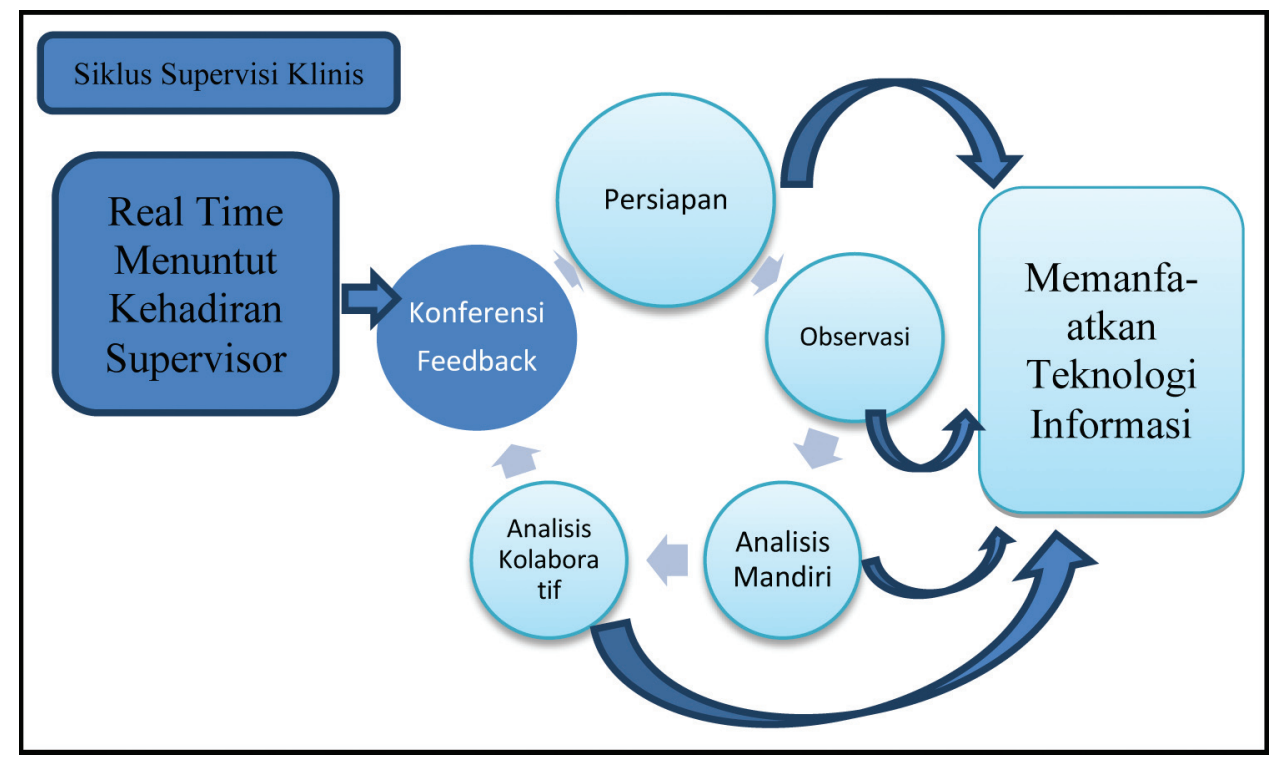

Gambar 5. Hasil Pengembangan Model Supervisi Klinis Berbasis Informasi dan Teknologi 
menyerahkan langsung dalam hardcopy pada model ini dilakukan melalui email. Supervisor dapat menganalisis melalui email dan dapat memberikan masukan kepada guru yang bersangkutan melalui email pula.

Untuk tahap observasi,supervisior tidak langsung masuk ke dalam kelas, tetapi dilakukan dengan melakukan rekaman video. Untuk melakukan rekaman ini diperlukan panduan yang dijadikan dasar untuk melakukan rekaman sehingga hasil rekaman sesuai kebutuhan dalam menganalisis hasil supervisi klinis. Pada hasil rekaman dapat dilihat dengan jelas selama proses pembelajaran secara utuh, mulai dari kegiatan pembukaan, inti dan penutup. Pada kegiatan pembukaan merekam kegiatan guru dengan close up sehingga jelas terlihat apa saja yang dilakukan dan dibicarakan oleh guru. Pada kegiatan inti dihasilkan rekaman gambar yang memperlihatkan kegiatan guru dalam mengelola pembelajaran, cara interaksi dengan siswa, dalam menggunakan metode, interaksi siswa selama pembelajaran, penampilan guru, yang menampilkan ekspresi ketika proses pembelajaran. Pada kegiatan penutup merekam kegiatan gambar aktivitas guru dan siswa saat mengakhiri pembelajaran di kelas.

Pada tahap analisis: pada model ini dikembangkan menjadi dua analisis. Analisis dilakukan oleh guru, guru memutar kembali rekaman video pembelajaran dirinya, kemudian melakukan self assessment yang berhubungan dengan kegiatan mengajarnya. Penilaian ini dilakukan dengan menggunakan format penilaian mengajar yang telah disediakan oleh supervisor yang dikirim melalui email. Setelah guru melakukan penilaian mandiri maka hasil tersebut dikirim kepada supervisor. Selanjutnya, dilakukan analisis kolaboratif berarti yang dilakukan oleh supervisor dalam hal ini dapat dilakukan oleh kepala sekolah atau oleh pengawas pembina. Penilaian juga dilakukan melalui tayangan rekaman video mengajar guru dengan menggunakan format penilaian yang telah disediakan. Setelah melakukan penilaian masingmasing aspek, melakukan analisis hasil pembelajaran tersebut, penilaian ini bersifat kolaboratif dengan menggunakan prinsip kesejawatan. Supervisor bukan seorang atasan tetapi sebagai kolega yang dapat membantu guru untuk memperbaiki mengajar. Penilaian ini menggunakan format penilaian yang telah disediakan.

Tahap akhir: tahap konferensi tahap pertemuan tatap muka langsung antara supervisor dan guru. Pada tahap inilah terjadi pertemuan kolegial membahas tentang proses pembelajaran guru yang bersangkutan, sambil melakukan pemutaraan ulang video tersebut, bila diperlukan pada tahap ini supervisor lebih banyak menggali hal-hal apa yang dialami oleh guru terkait kemampuan mengajarnya. Pada tahap ini pengawas tidak banyak memberikan saran kepada guru tetapi lebih banyak menggali hal-hal apa yang dinilai guruperlu untuk diperbaiki dalam upaya meningkatkan kompetensi mengajarnya.

Menurut pendapat guru dengan model supervisi berbasis teknologi dan informasi supervisi klinis dapat dilakukan secara lebih alamiah, pada kondisi ini guru tidak merasa sedang dinilai keeterampilan mengajarnya karena supervisor tidak hadir langsung di kelas, kedua guru juga merasa perlu untuk dievaluasi kelebihan dan kekurangannya, terutama kekurangan yang sulit untuk diungkap, karena merasa sudah baik dalam mengajar. Dengan melihat rekaman video mengajar guru dapat melihat secara langsung tentang keterampilan mengajarnya terutama dalam hal mengelola siswa di kelas untuk dapat belajar dalam kondisi yang menyenangkan dan mencapai daya serap yang tinggi. Kepala sekolah menilai model ini sangat membantu untuk memberikan pembinaan guru-gurusecara professional, dengan mengedepankan self assessment sehingga tidak terkesan kepala sekolah menunjukkan kekurangan guru, tetapi perbaikan dilakukan berdasarkan fakta dan kesadaran ataupun keinginan dari guru itu sendiri.

Supervisor dalam hal ini pengawas pembinan menilai model supervisi klinis berbasis teknologi dan informasi sangat efektif dilihat dari keterbatasan waktu yang dimiliki oleh pengawas mengingat banyak sekali guru yang harus dibina dalam satu wilayah binaan, komunikasi pembinaan antara pengawas dan guru di wilayah binaan terjalin baik, karena dapat dilakukan melalui SMS, mengirim email atau menelpon langsung ke handphone. Model supervisi ini sangat sesuai untuk membinan guru yang mengalami masalah khusus dalam pembelajaran.

Studi awal menemukan bahwa persepsi guru dan kepala sekolah tentang supervisi klinis belum dipahami secara optimal, karena supervise yang dilakukan disekolah adalah supervisi akademik, Kegiatan supervisi akademik adalah supervise yang dilaksanakan oleh kepala sekolah dan pengawas sebagai program manajerial rutin 
untuk mengetahui ketercapaian hasil pembelajaran pembelajaran. Sedangkan supervisi klinis merupakan supervisi yang difokuskan kepada perbaikan keterampilan mengajar pada satu aspek keterampilan seperti keterampilan menjelaskan. Hal ini didukung oleh hasil penelitian Iriani (2008: 278-285) pada studi awal pemahaman kepala sekolah terhadap supervisi klinis kurang baik, setelah penelitian berkembang menjadi sangat baik dan mampu melaksanakan supervisi klinis secara tepat, sehingga kesulitan dalam menggunakan keterampilan dasar mengajar dapat diperbaiki.

Penelitian Baltacyi-Goktalay et al (2014:111) mengembangakan penelitian model supervisi klinis berbasis informasi dan teknologi (IT) menemukan bahwa keberadaan sistem UludagKDM, membutuhan pengujian kembali atau media sosial lain harus dapat dipertimbangkan untuk tujuan komunikasi dan umpan balik. Pada proses penelitiannya tiap tahapan guru yang dioberavasi melakukan komunikasi melalui sistem UludagKDM, pada prosesnya belum optimal sistem tersebut digunakan oleh guru (peserta yang dilatih), guru pendamping dan pihak universitas. Sebagian guru yang dilatih memiliki opini negatif terhadap sistem tersebut dan facebook dijadikan salah satu opsi atau pilihan, facebook dianggap lebih baik, tetapi facebook bukan untuk tujuan ilmiah, maka diputuskan untuk membuat kursus untuk menggunakan sistem UludagKDM, tetapi dibuat untuk lebih menyenangkan dalam menggunakannya.

Penelitian ini juga didukung hasil penelitian Pengembangan Paket Program Coaching Berbasis Video untuk Peningkatan Kompetensi Mengajar Guru Sains. Setelah menggunakan paket program coaching, guru lebih menyadari bahwa membuka dan menutup pelajaran bukanlah sekedar mengucapkan salam, atau memeriksa kehadiran siswa, tetapi membuka dan menutup pelajaran memiliki makna penting dalam pembelajaran (Widodo, Riandi dan Supriatna, 2011:58-72). Didukung pula hasil penelitian Saputra melalui perlakuan (model pengawasan pembelajaran) ternyata kompetensi akademik dapat meningkat dan tentunya dapat memberi dampak terhadap kualitas pengajaran bagi para siswanya. Jadi, model pengawasan pembelajaran yang dikembangkan terbukti efektif dalam meningkatkan kompetensi akademik guru pendidikan jasmani di SD (Saputra,2011:485486).
Terkait dengan pengunaan panduan supervise klinis berbasis teknologi dan informasi menurut pandangan para user yang menjadi subyek sasaran penelitian dalam hal ini pengawas, kepala sekolah, guru dan kameramen, dari sisi panduan dan instrument menurut para pengguna: guru, pengawas, kepala sekolah dan kameramen bahwa panduan supervisi klinis dan panduan rekaman video sudah sangat jelas, mudah dimengerti dan mudah untuk diaplikasikan oleh pengguna.

\section{PENUTUP}

Model supervisi klinis berbasis informasi dan teknologi merupakan model yang dikembangkan dari konsep supervisi klinis Glickman meliputi tahap persiapan (pra observasi), observasi, analisis mandiri, analisis kolaboratif, konferensi dan feedback.Tiap tahap supervisi klinis dapat dilakukan melalui pemanfaatan teknlogi dan informasi. Pada tahap persiapan, dilakukan dengan pengiriman short message service (SMS), email atau menelpon langsung untuk menetapkan waktu supervisi dan mempersiapkan rencana pembelajaran. Tahap observasi pembelajaran dilakukan dengan rekaman video.Tahap analisis mandiri, guru menggunakan rekaman video dan insrumen supervisi klinis dan pada tahap analisis kolaboratif, pengawas menggunakan rekaman video dan insrumen supervisi klinis. Pada tahap pertemuan balikan, supervisor harus bertemu langsung dengan guru untuk mendiskusikan hasil analisis penilaian mandiri dan analisis kolaboratif. Semua tahapan tersebut memanfaatkan informasi dan teknologi kecuali pertemuan balikan langsung bertatap muka untuk menghasilkan hubungan kolaboratif yang harmonis. Dalam pelaksanaan seluruh tahapan supervisi klinis, supervisor dan guru menggunakan panduan supervisi klinis, instrumen supervisi klinis, dan panduan rekaman video yang digunakan dalam proses rekaman.

\section{UCAPAN TERIMA KASIH}

Terima kasih saya haturkan kepada Direktorat Jenderal Pendidikan Tinggi dan Universitas Negeri Jakarta yang telah memberikan dana penelitian ini melalui penelitian hibah bersaing, terima kasih pula kepada tim redaksi Jurnal Cakrawala Pendidikan dan para reviwer dan admni yang telah memberikan kesempatan dan membantu saya untuk mempublikasikan hasil penelitian pada jurnal ini. 


\section{DAFTAR PUSTAKA}

Baltacyi-Goktalay et al. 2014. Clinical Supervision Model And Uludag Kdm. International Journal on New Trends in Education and Their Implications. April 2014 Volume: 5 Issue: 2 Article: 01 ISSN 1309-6249. dari :http://www.ijonte.org/FileUpload/ ks63207/File/01a.baltaci-goktalay.pdf. diunduh 18 Juni 2016.

Esim et al. 2013. Clinical Supervision Model to Improve Supervisory Skills of Cooperating Teachers and University Supervisors during Teaching Practice.H. U. Journal of Education Özel Sayý (1), 191-203.online:https:// www.researchgate.net/profile/Umut Salihoglu/publication/259169324_ Clinical Supervision Model to Improve_Supervisory_Skills_of_Cooperating_Teachers_and_University_Supervisors_during_Teaching_Practice/ links/542d38d50cf29bbc126d21bd.pdf.

Borg, Walter R; Damien Gall. 2008. Educational Research. New York: Pearson Education, Inc.

Glickman, Carl D., Stephen P. Gordon \& Jovita M. Rose-Gordon. 2010. Supervision and Instructional Leadership. New York: Pearson.

Harris, Mary \& Anne Brockbank. 2011. An Integrative Approach to Therapy and Supervision. London: Jessica Kingsley Publishers.

Hess, Kären Matison., Christine Hess Orthmann. 2012. Management and Supervision in Law Enforcemen. USA : Delmar.

Iriani, Dwi. 2008. Pengembangan Supervisi Klinis Untuk meningkatkan Keterampilan Dasar Mengajar Guru. Jurnal Didaktika,
Vol.2 No.2 Maret 2008. Online: https:// utsurabaya.files.wordpress.com/2010/08/ dwi-iriyani.pdf.

Kevin Wu. 2010. Quality Implementation. Jakarta: Gramedia Pustaka Utama.

Openshaw, Linda. 2012. Challenges In Clinical Supervision. USA : NACSW Convention.

Mulyana, A.Z. 2010. Rahasia Menjadi Guru Hebat. Surabaya : Grasindo.

Saputra, Yudha M. 2011. Model Pengawasan Pembelajaran Pendidikan Jasmani Di SD. Cakrawala Pendidikan, November 2011, Th. XXX (3), 474-489, online:http://download.portalgaruda.org/article.php?article $=3$ 24630\&val $=445 \&$ title $=$ MODEL $\% 20$ PENGAWASAN\%20PEMBELAJARAN\%20 PENDIDIKAN\%20JASMANI\%20DI\%20 SD diunduh 20 Juni 2016.

Sergiovanni, Thomas \& Robert Starratt. 2006. Supervision : A Redefinition. USA: McGrawHill Education.

Sullivan, Susan and Jeffrey Glanz. 2013. Supervision That Improves Teaching and Learning. USA : Sage Publications Ltd.

Widodo, Ari., Riandi, \& Bambang Supriatno. 2011. Pengembangan Paket Program Coaching Berbasis Video Untuk Peningkatan Kompetensi Mengajar Guru Sains. Cakrawala Pendidikan, Februari 2011, Th. XXX (1), 58-72, online: https://lppmp. uny.ac.id/sites/lppmp.uny.ac.id/files/5\%20 Ari\%20Widodo,\%20Riandi,\%20dan\%20 Bambang\%20Supriatno\%20bagian\%201. pdf. diunduh 20 Juni 2016. 